enough to justify an important diversion of resources?

Lastly, we cannot answer Professor A G Johnson's questions about deaths with peritonitis, save to say that evidence of severe sepsis was often lacking, and that precise description of any cause of death is frequently difficult; there were inevitable surgical failures, but elderly tissues do not heal well.

Michael AtKinson M J S LANGMAN

University Hospital and

Department of Therapeutics,

${ }^{1}$ Hunt PS, Hansky J, Korman MG. Br Med f 1979 ; : 1238-40.

\section{Population growth and contraception in Africa}

SIR,-Dr P V F Cosgrove's letter (20 March, p 900) raises an important issue regarding food shortages and population growth in Africa. The problem of famine is often associated with population explosion. The average African has $10 \%$ less to eat than 10 years ago. Hence the conclusion is drawn that the main way to overcome it is to control fertility. Typical of that position is the assertion that population limitation is the preliminary condition for any radical improvement of the human condition.

But there is another point of view put forward by those who refuse to recognise that accelerated growth of population in African countries is creating specific problems. They look on the human resources as the most positive factor in promoting socioeconomic development. They deny any need for measures to control fertility. Their attitude stems from the underestimation of the definite interdependence of demographic and economic factors, and ignores the important dialectical proposition that demographic factors, although secondary and dependent in relation to social production, may and do exert an active reverse action on economic and social progress.

Some family planning programmes are now being implemented in certain African countries usually with the assistance of Western governments and organisations. It must be pointed out, however, that with the possible exception of Nazi Germany, no government in an industrial country has ever attempted to impose population control on one class or group within its own society. Readers of this journal will be aware that rural couples in Africa have always used a combination of lactation and sexual abstinence to protect the health of mothers and their offspring. Breast feeding has so far been the most successful natural method of family planning. A recent statement by the International Medical Advisory Panel of the International Planned Parenthood Federation, the foremost family planning organisation in the world asserted that: "Lactation worldwide is estimated to prevent more births than all organised family planning programmes and thus has a definite contraceptive action. In addition, it contributes to better infant nutrition and wellbeing."' Small wonder though, not much emphasis is put on this method as in the artificial contraception by the International Planned Parenthood Federation in its effort to promote family planning programmes in its 108 family planning member associations all over the world.

The striving of the governments in Africa to include measures for fertility control in their programmes of economic development is quite justified in principle. But it is wrong to reduce the whole significance of family planning programmes in developing countries to the demographic and economic aspects of the matter. As a rule family planning should be an integral part of State measures to protect the health of mothers and children. In this way it can immediately produce very useful results by lowering the very high maternal and infant mortality. The International Planned Parenthood Federation has always empha sised this aspect of family planning.

There is less support, however, for measures to reduce population growth in Africa than might be assumed. Even if there were agreement on this aim there is still the question of how best to achieve this objective. The ratios of man to land in Africa are among the lowest in the world. If a great part of the uninhabitable land is made suitable for settlement by, for example, the elimination of the tse-tse fly then Africa may not have a problem of overpopulation due to land shortage.

There are many factors responsible for lagging food production in Africa: droughts and livestock shortages created by them; tse-tse fly; and liberation struggles have affected agricultural and rural development in a number of countries. Neither have agricultural development programmes made adequate progress. The prospects for sufficient food supply remain disquieting for the rest of the century in sub-Saharan Africa. With an average of about $3 \%$ increase in population a year food demands continue to outstrip domestic supplies, and great pressure is placed on the import capacity of individual countries. Attempts to solve food production and accompanying import problems have failed due to inability to increase farm production per worker. Although food aid brings temporary relief and benefit, its control is an opportunity for exploitation and a potential instrument of power by donors. The food and nutrition situation is precarious-a primary deficiency of protein associated with lack of energy, or calories, is common in young children between the ages of 1 and 4 throughout the continent.

African governments should design and formulate policies and programme strategies which favour the development of the food sector. It is clear that unless policies change and there is a great improvement in agricultural performance, the rate of growth of production will lag behind the growth in demand for all the commodity crops.

SHADRACK E MUNISI

Committee for the Organisation of

Black Studies Library,

' International Planned Parenthood Federation: International Medical Advisory Panel, Statement on contraception and lactation. London: IPPF, 1981.

SIR,-The correspondence on population growth and contraception in Africa-Dr A R P Walker and others (27 February, p 657) and Dr P V F Cosgrove (20 March, p 900)illustrates the historical and demographic trap into which most of the peoples of the so-called Third World, but especially in Africa, are falling.

On the other hand social factors which motivate peasant peoples to try limiting their families and adopting contraceptive practices start to operate only in a climate of progressively rising standards of living. (In this connection it is interesting that from $\mathrm{Dr}$ Walker and other's figures this appears to be happening in South Africa, where African peoples are relatively more prosperous than elsewhere.) On the other hand, while it is undoubtedly possible by modern agricultural methods to feed adequately the burgeoning population of these countries the lack of suitable education, development, and infrastructure prevents the acceptance of these methods and the proper distribution of food supplies to where they are needed. Historically it is a tragedy that these newly emergent nations do not have the time which is required to bring about changes in their own societies to meet these problems, which normally might be expected to span several generations before the population bomb explodes in their faces, leaving a trail of untold human misery with great political instability and dangers to world peace. The cynical exploitation of the situation by certain outside countries who are simply running guns to dissident groups for political purposes serves only to compound the problems.

Apart from the Brandt Commission and the Western summit meeting last year, there seems little international recognition of the magnitude and urgency of the problem. What is required is a massive programme on an international scale rather on the lines of Marshall Aid after the war to provide food and the means of its production, and to exert moral pressure on those nations displaying a negative attitude towards the problems by the conclusion of an Helsinki-type agreement. At the same time a new economic order needs to be set up whereby Third World nations are enabled to sell their products at advantageous rates thus stimulating the growth of their economies and creating expanding markets for world trade. Without attention to such matters all efforts of medical and allied personnel to improve the health and quality of life of these peoples, will be to no avail and, indeed, may serve to aggravate the problem-by disease control, etc. The medical profession in many countries is currently concerning itself with the medical consequences of nuclear warfare. I should like to suggest it addresses itself to the problems of population growth with equal vigour as it is not too fanciful to suggest they are related problems.

G A B Cunningham

Cranbrook, Kent TN17 5LG

SIR,-Most medical practice in Africa and similar environments in the Third World is influenced by the unequal equation of malnutrition. On one side is the ever increasing population and on the other is food availability.

When I first went to Africa 20 years ago as a young scientifically trained obstetrician I too held the beliefs expressed by Dr P V F Cosgrove (20 March, p 900). All that was required to solve the equation was, "the efficient use of the agricultural inputs: water, fertiliser, pesticide, and farm machinery," just as, I believed, all that was required to solve the problems associated with childbirth was the efficient use of modern obstetric technology.

It took me 10 years of bitter experience to discover that it was the other side of the equation which required prime attention to alleviate the sufferings of nutritional deprivation and difficult childbirth, which are closely related. The pouring in to the Third World of megatonnes of fertiliser, pesticide, farm machinery etc, the stuff that "agribusinesses" are made of, will only temporarily alleviate the problem, as the green revolution has shown.

By stating that the developed world uses $85^{\circ}$, of the world's fertiliser and no doubt $85 \%$ of the world's pesticide, etc, with continually diminishing returns for increasing effort and expense, Dr Cosgrove really means that the developed world now feeds itself by a kind of hydroponic agriculture. This has come about solely because the developed world has been grossly overpopulated for 